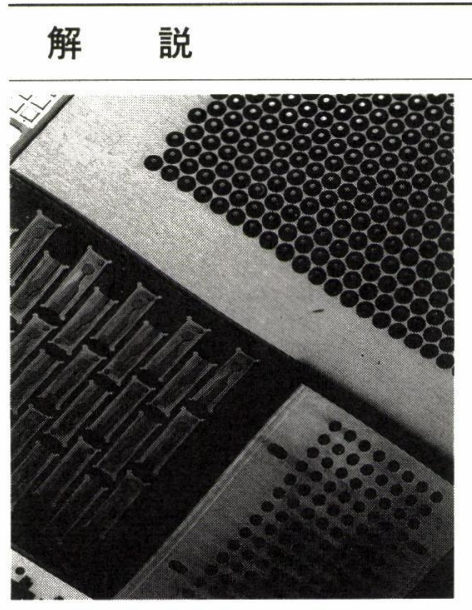

特集・マイクロエレクトロニクスにおける制御

\section{ロボット制御の基礎 センサ及びアクチュエータ技術}

A Contorol of Roboto

Sencer and Actuater Technology

西井 完治* 河村 浩幸* 米澤 武敏*

\section{1.はじめに}

ロボット制御は, メカトロニクスの代表的な技術分野 である。メカトロニクスとは，いうまでもなく従来のメ カニクス（機械技術）に最新のマイクロエレクトロニク スを応用する事で発展してきた技術である。

このロボット制御を構成する主な要素として,

1）センサ技術 [感覚認識機能]

2）アクチュエータ技術 [作業機能]

3） AI (人工知能) 技術 [大脳機能] があげられる。

一般のメカトロニクスと同様に，このロボット制御に おいても，より高速で，より高精度な制御を行うために は, センサおよびアクチュエー夕の応答性, 分解能, 精 度等が重要なファクタとなっている。

そこで，本報告ではロボットにおけるセンサ技術およ びアクチュエータ技術を主に取り上げ，それらのロボテ イクス (ロボット工学) における位置付け, 最近の開発 動向等について報告する。

\section{2.ロボットの進化と機能}

Fig.1 ${ }^{1)}$ は、ロボットの進化とその特徵を示したもので ある。眓中の感覚認識機能のうち, 内界情報とはロボッ 卜自身に関する情報, 例えばアーム駆動モー夕の回転角 等の情報を指す。一方，外界情報とは作業対象あるいは

*Kanji Nishii, Hiroyuki Kawamura, Taketoshi Yonezawa 松下電器デバイス工法開発研究所/Matsusita Electric Industrial Device Process Technology Research Laboratory

Vol.5, No.4
作業空間に関する情報，例えば対象物体までの距離情報 等を指す。Fig.1から分かるように，すべてのロボットに おいて, 先ほど述べた要素技術が全部必要なわけではな w。

しかし，近年普及レベルに達した第 2 世代以降のロボ ットにおいては，NIES 製品の台頭等の社会的ニーズを 踏ま之た高付加価值製品の生産を実現する知能化ロボッ ト，すなわち，“より人間に近いロボット”の研究開発が 盛んになってきている。こうした“より人間に近いロボ ット”においては，とりわけ人間の五感に匹敵するよう な感覚認識機能を実現するセンサ技術が重要な要素技術 として位置付けられる。

\section{3.ロボット用センサ}

\section{1 ロボット用センサの要件}

ロボット用として特別に開発されたセンサはそれほど 多くはないが，ロボット開発の究極の目的は, “1台の機 械（ロボット）で多品種を無人で24時間生産できる無人 化工場を実現する事”である。

従って, ロボット用センサには,

1）人間の五感に相当する機能の実現

2）悪環境下での長期信頼性の確保

3）可動部に搭載可能な小型化

等が, 主に要求される。

\section{2 内界センサと外界センサ}

ロボット用センサは，その用途から内界情報を検出す る内界センサと, 外界情報を検出する外界センサに大別 できる。内界センサは，位置制御，モー夕回転制御に用 いられる“位置センサ”, 速度制御に用いられる“速度セ ンサ”，振動対策に用いられる “加速度センサ” 等に分類 


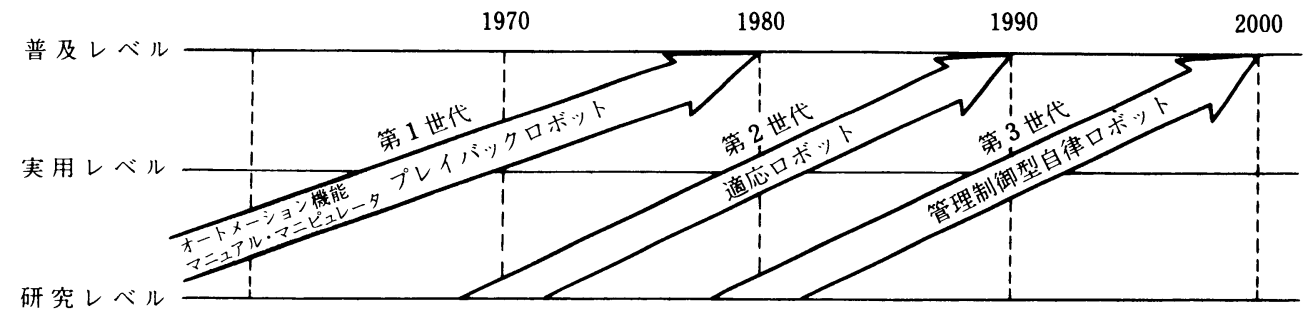

\begin{tabular}{|c|c|c|c|c|}
\hline & & 第 1 世代 & 第 2 世代 & 第 3 世代 \\
\hline \multirow{2}{*}{$\begin{array}{c}大 \text { 脳機 能 } \\
(\text { 小脑 })\end{array}$} & 知 能 & $\begin{array}{c}\text { 先天的 } \\
\text { (プレイバック) }\end{array}$ & 適応 - 順応 & $\begin{array}{c}\text { 後天的 } \\
\text { (学習·推論·問題解決) }\end{array}$ \\
\hline & 知 識 & データ & データベース & 知識ベース \\
\hline & 内界情報 & あり & あり & あり \\
\hline 感賞認識機能 & 外界情報 & なしあるいは点 & $\begin{array}{l}1 \text { 次元 } \cdot 2 \text { 次元 } \\
\text { 整った環境 }\end{array}$ & $\begin{array}{l}3 \text { 次元 } \\
\text { 自然環境 }\end{array}$ \\
\hline
\end{tabular}

\begin{tabular}{|c|c|c|c|c|}
\hline \multirow[t]{2}{*}{ 感賞認識機能 } & & & 整つた境境 & 自然罜境 \\
\hline & コミュニケーション & $\begin{array}{c}\text { 一方向 } \\
(\text { ティーチング, } \mathrm{NC} \text { テープ) }\end{array}$ & $\begin{array}{l}\text { インタラクティブ } \\
\text { (ロボット用言語) }\end{array}$ & $\begin{array}{r}\text { 双方向コミュニケーショ } \\
\text { 管理制御, テレイグジスタンス, } \\
\text { 間コミュニケーション, 自然言語 }\end{array}$ \\
\hline 機 能 & マニピュレーション & 静的位置制御 & 動的位置制御 & 動的力制御 \\
\hline IF柰便胒 & 移 動 & 1 次元 $\cdot$ 軌道 & 2 次元 - 無軌道 & 3 次元 \\
\hline 応 用 範 囲 & & $\begin{array}{l}\text { 第 } 2 \text { 次産業製造業の一部 } \\
\left(\begin{array}{l}\text { マテリアルバリングン } \\
\text { 塗装・スポット溶接 }\end{array}\right)\end{array}$ & $\begin{array}{c}\text { 第 } 2 \text { 次産業製造業 } \\
\left(\begin{array}{l}\text { アーク溶接 } \\
\text { 組立 }\end{array}\right)\end{array}$ & $\begin{array}{l}\text { 第 } 2 \text { 次産業非製造業 } \\
\text { 第 } 1 \text { 次産業 } \\
\text { 第 } 3 \text { 次産業 }\end{array}$ \\
\hline
\end{tabular}

Fig.1 Evolution of robot



Fig.2 Piezoelectric Accelerometer

できる。

一方, 外界センサは部品の認識, 欠陥の検出等に用い られる“視覚センサ”, 対象物体の探索，確認に用いられ る “接触覚センサ”, 把握力検出に用いられる “圧覚セン サ”および“すべり覚センサ”，押圧制御に用いられる“力 覚センサ”, ロボットの移動制御等に用いられる“距離セ ンサ”および特に近距離で用いられ高精度距離検出を行 う“近接覚センサ”等に分類できる。

またロボット制御との関係から見ると，内界センサは ロボットアーム等のフィードバック制御に主に用いられ る。一方, 外界センサはロボットの行動制御すなわち行 動計画, 知識データベースとの照合による認識等に用い
られる。従って内界センサには主として精度, 応答性が 要求され, 外界センサには高機能, インテリジェント性 が求められている。このような観点から最近開発された センサのいくつかを紹介する。

\subsection{1 加速度センサ（圧電型加速度センサ）}

Fig. ${ }^{2)}$ は, 外力により圧電素子が歪むと電荷が発生す る “圧電効果”を利用した圧電型加速度センサのセンシ ング部の基本構造である。片持ち梁型にレーザ加工によ り構成した圧電素子の振動子に加わる加速度を, 素子に 発生する電荷から検出する原理である。温度変化補償回 路を付加する事で, - $40 \sim+125^{\circ} \mathrm{C}$ の広い温度範囲で $1 \%$ オーダの出力值線性を, 従来の加速度センサと比較して 簡単な構造で実現している。

\section{2 .2 位置センサ（リニアスケール）}

Fig. ${ }^{3)}$ は約 $0.5 \mu \mathrm{m}$ のピッチの格子パターンを記録し た体積型位相ホログラムを用いたホログラフィックリニ アスケールの検出光学系の原理困である。半導体レーザ から出射された光は, PBSにより2つにわけられスケー ルのホログラムにより各々 2 度ずつ回折される。その際, 両者の回折角の正負が逆のため逆位相が付加され反射光 が検出器上で干渉する。この干渉縞の強度を検出するこ とで格子ピッチの $1 / 4$ の精度で移動量を検出できる。さ らにへテロダイン検波を併用することで $0.01 \mu \mathrm{m}$ オ一 


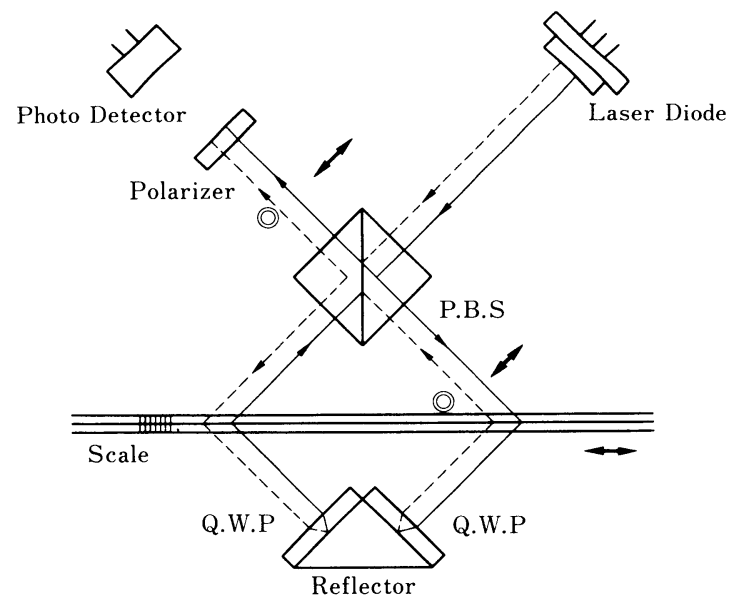

Fig.3 Holographie Linear Scale

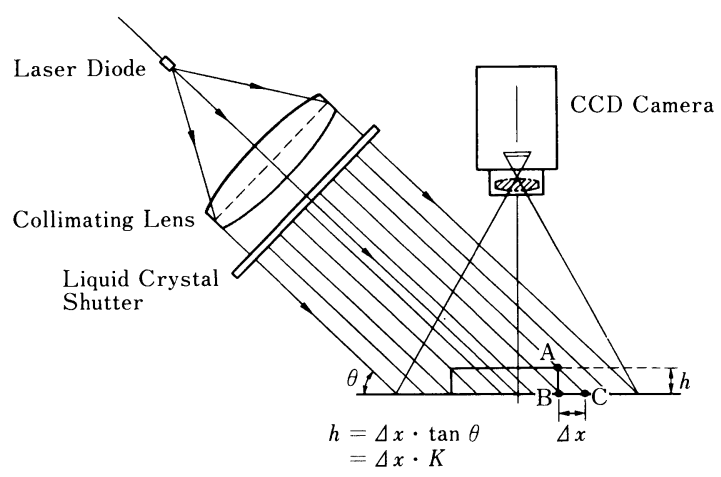

Fig.4 $3 \mathrm{D}$ Range Finder

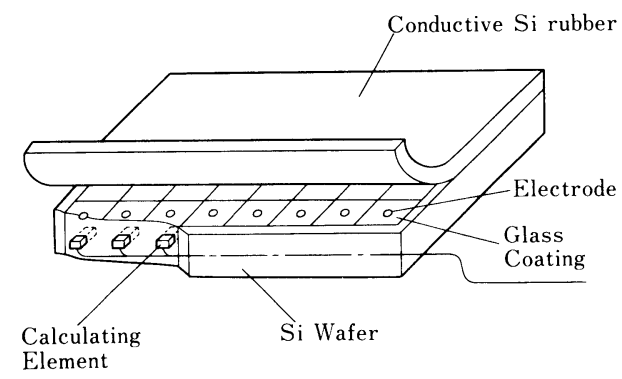

Fig.5 VLSI Tactile Array Sensor

\section{ダの精度を実現している。}

\section{2 .3 視覚センサ ( 3 次元距離センサ)}

Fig. $4^{4)}$ は，対象物体に対して一定角度に設定した液晶 シャッタとレーザ平行光源による面パターン投光装置と 対象物体の真上に設置した CCD カメラを用いた 3 次元

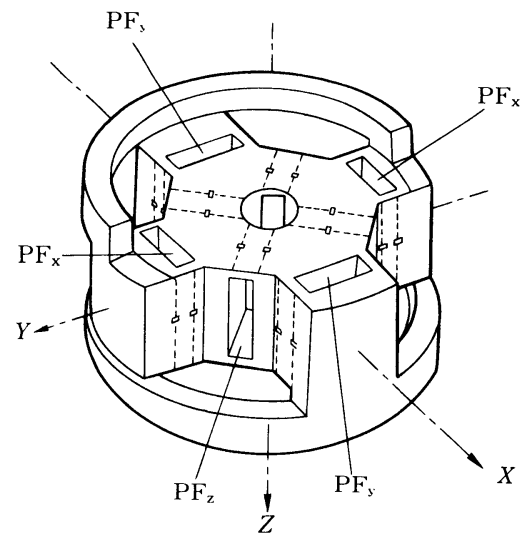

$\mathrm{PF}_{\mathrm{x}}$ : Parallel Plates For $\mathrm{X}$-direction Force $\mathrm{PF}_{\mathrm{Y}}$ : Parallel Plates For $\mathrm{Y}$-direction Force $\mathrm{PF}_{\mathrm{Z}}$ : Parallel Plates For $Z$-direction Force

Fig.6 Crasping Force Sensor

距離センサの原理図である。半導体レーザから出射され た光は，レンズ系により平行光化され液晶シャッターに よりピッチ $100 \mu \mathrm{m}$ の 256本の縞状パターン化される。こ の面パターン画像上の縞には空間符号化法により番号付 けしている。この符号化画像の濃淡を 2 值化し画像処理 を行い，縞ピッチと番号とから Fig.4の $\Delta x$ を求め, 高さ $h$ を算出することで高速な三次元認識を実現している。

\subsection{4 圧賞センサ (VLSI 圧覚センサ)}

Fig. (5) $^{5}$ は，半導体製造技術を利用した高密度インテリ ジェント圧覚センサの構成困である。導電性シリコンゴ ムの下に絶縁層と金属接点を置き，それぞれの接点に対 応して1つずつプロセッサを共通のシリコンウェハ上に 構成したものである。ロボットハンドによる圧力印加に より変化する接点間の抵抗值を検出することで 2 次元压 力分布を検出できる。また組み込みのアレイプロセッ开 により圧力信号に対して，空間フィルタリング処理を行 いその結果をシリアルデータに変換して出力するので, 情報圧縮, 信号線のチャンネル数低減が同時に行える。

\section{2 .5 カ覚センサ（ 6 軸カセンサ）}

Fig.6) は，ロボットの手首にかかる6 軸（XYZ 軸と, そのまわりの回転) の力を検出する力覚センサの構造図 である。 3 組の平行平板と歪みゲージとから構成されて いる。平行平板を用いることで, 例えばX方向に力を加 えた時にY及びZ方向の力を検出する歪みゲージの出力 が非常に小さくなる。すなわち各軸間の干渉防止が図れ る。これにより, 構造の簡略化, 手首着装可能な小型化 を実現している。

\subsection{6 近接覚センサ（光学式近接覚センサ）}




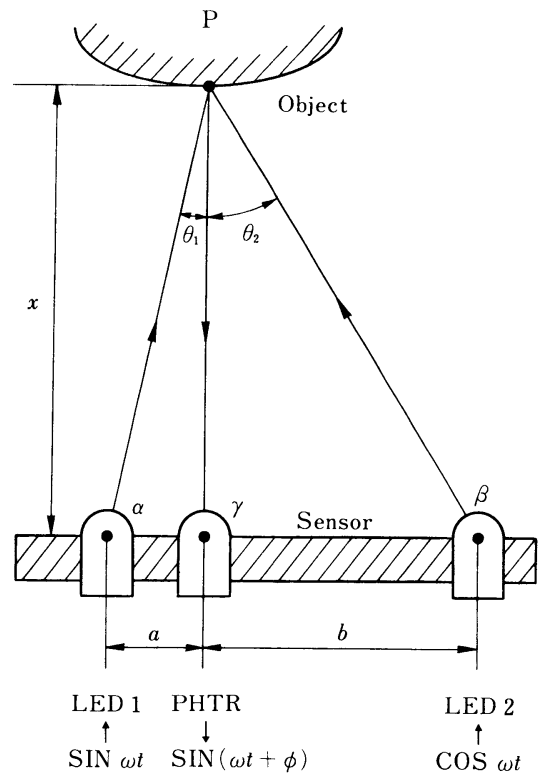

Fig.7 Optical Proximity Sensor

Fig. $7^{7)}$ は，基本的には反射光量から対象物体までの距 離を測定する光学式近接覚センサの原理図である。LED 1, LED 2 は光源であり受光素子 PHTR に対して非対 称の位置に配置されている。この 2 つの光源の輝度を互 いに $90^{\circ}$ 位相のずれた $\sin \omega t, \cos \omega t$ のごとく時間的な 変調を与える。従って, 受光素子により検出される対象 物体からの反射光量の和は $\sin (\omega t+\phi)$ で表される位相 ずれ $\phi$ を持つ。この位相ずれ $\phi$ は距離 Xの関数となる ので，位相検波により距離検出を行うことができる。ま た，位相ずれ $\phi$ を用いることで対象物体の反射率に影響 されない距離測定が可能であるという特徵を持っている。

\section{4. センサとアクチュエータの協調制御}

センサとアクチュエータの協調制御の代表例としてコ ンプライアンス制御とハンド・アイシステムの 2 つを取 り上げる。

\section{1 コンプライアンス制御}

VTR 等の精密部品のはめ合い等 $\mu \mathrm{m}$ オーダの精密作 業, 柔らかい物体の把握といった作業の場合, 力と位置 の両方の制御が必要になる。コンプライアンスとは“柔 らかさ”を意味し, 力学的には剛性 (ばね定数) の逆数 すなわち(位置)/(力)で定義されるものである。従って， このコンプライアンスを制御することで結果的に位置制 御と力制御の両方を行った事になる。

具体的にはFig.8 ( ) $^{8}$ のば定数 K を調整する制御であ 26
Robotic Arm

$\left(K_{e}\right)$
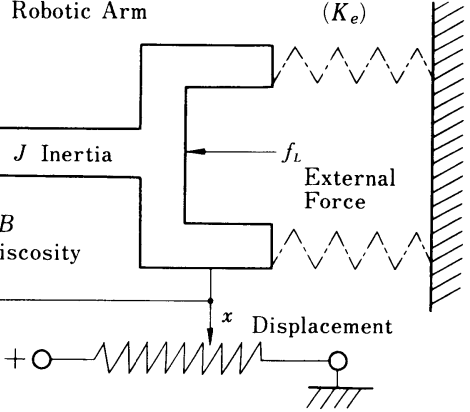

Fig.8 Compliance Control

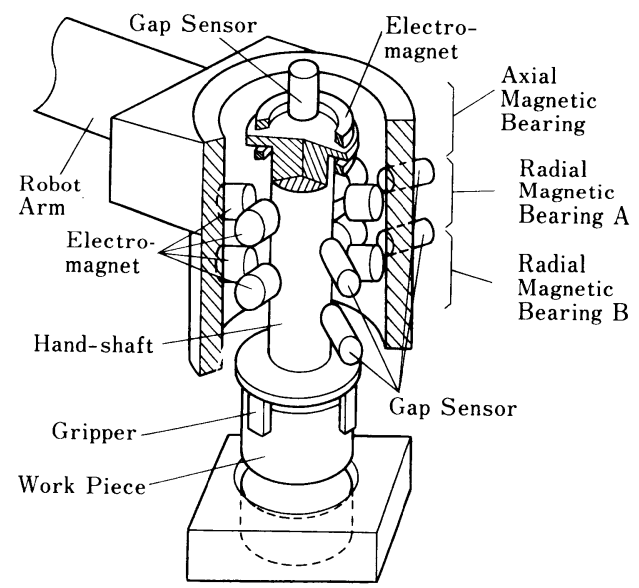

Fig.9 Magnetically Supported Hand

ク, 位置センサ及び Fig.5の圧覚センサ, Fig.6の力覚セン サをセンサとして用い，アクチュエータとして，例えば Fig.99)に示した磁力支持ハンドが用いられる。これは電 磁石の吸引力を変化させることで， 5 軸のコンプライア ンス制御を行うものである。

\section{2 ハンド・アイシステム}

ロボットハンドと視覚の協調制御であるハンド・アイ システムは, 様々な環境に適応し自律的に作業を行う自 律ロボットの制御技術の 1 つである。ハンド・アイシス テムは言語系, 認識系, モデル系の 3 つのサブシステム から構成される。言語系にはプランニング機能から動作 レベルの言語まで含まれる。認識系では視覚情報（触覚 情報）に基づいて対象物体の位置・姿勢を認識する。モ デル系は作業環境に関する情報, アームの動特性, カメ ラに関するセンサ情報等が含まれ, 言語系及び認識系に 対してロボット環境情報のデータベースを提供する。

具体的には Fig.1010)に示したように，電子計算機，多 自由度を有するロボットアーム, 濃淡画像を入力する

HYBRIDS 


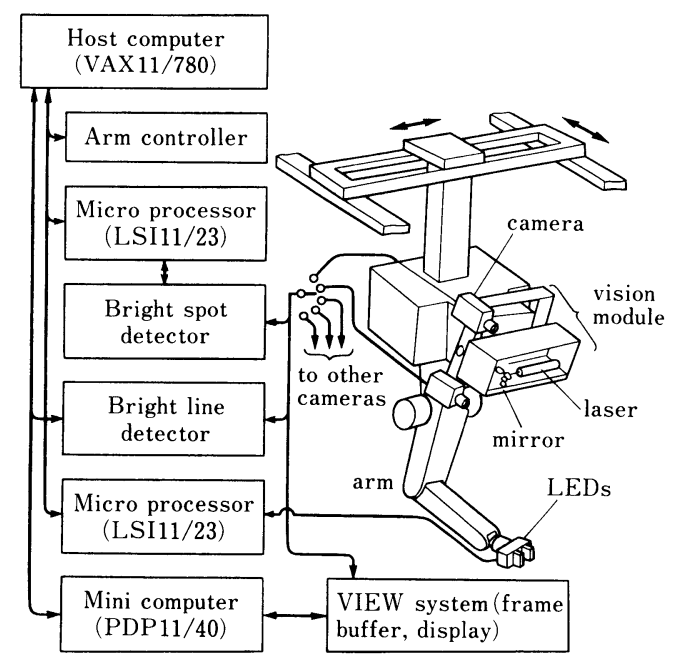

Fig.10 Hand Eye System

$\mathrm{TV}$ カメラ及び距離データを入力するレーザ測距計等か ら構成されている。

\section{5. 知的ロボット制御技術}

新しいロボット制御技術の代表例として，人間の右脳 が持つといわれている優れたパターン認識能力（並列情 報処理機能）をロボット制御に取り入れる事で，ロボッ 卜の高度知能化を目指寸知的ロボット制御技術について 述べる。その例として，二ューロロボット及び光情報処

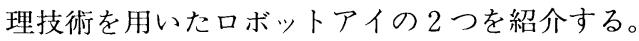

\section{1 ニューロロボット（同時並列型情報処理）}

ニューロロボットは，人間の脳をモデルとして並列的 に動作するニューロ素子を相互に結合したネットワーク を構成し並列分散処理と学習を行うニューロコンピュー 夕による制御技術を用いたロボットである。

具体的には, Fig.1111)に示したように超音波センサ, 光 センサ，タッチセンサ，リミットセンサの入力を受け， ニューロコンピュータの出力でロボットのモータを制御 して前進, 後進, 左右回転を行うものである。このニュ 一ロコンピュータは “探索行動”を受け持つ“理性ネッ トワーク”と，“回避行動”を受け持つ“本能ネットワー ク”と呼ばれる 2 つの階層ネットワークからなり長期記

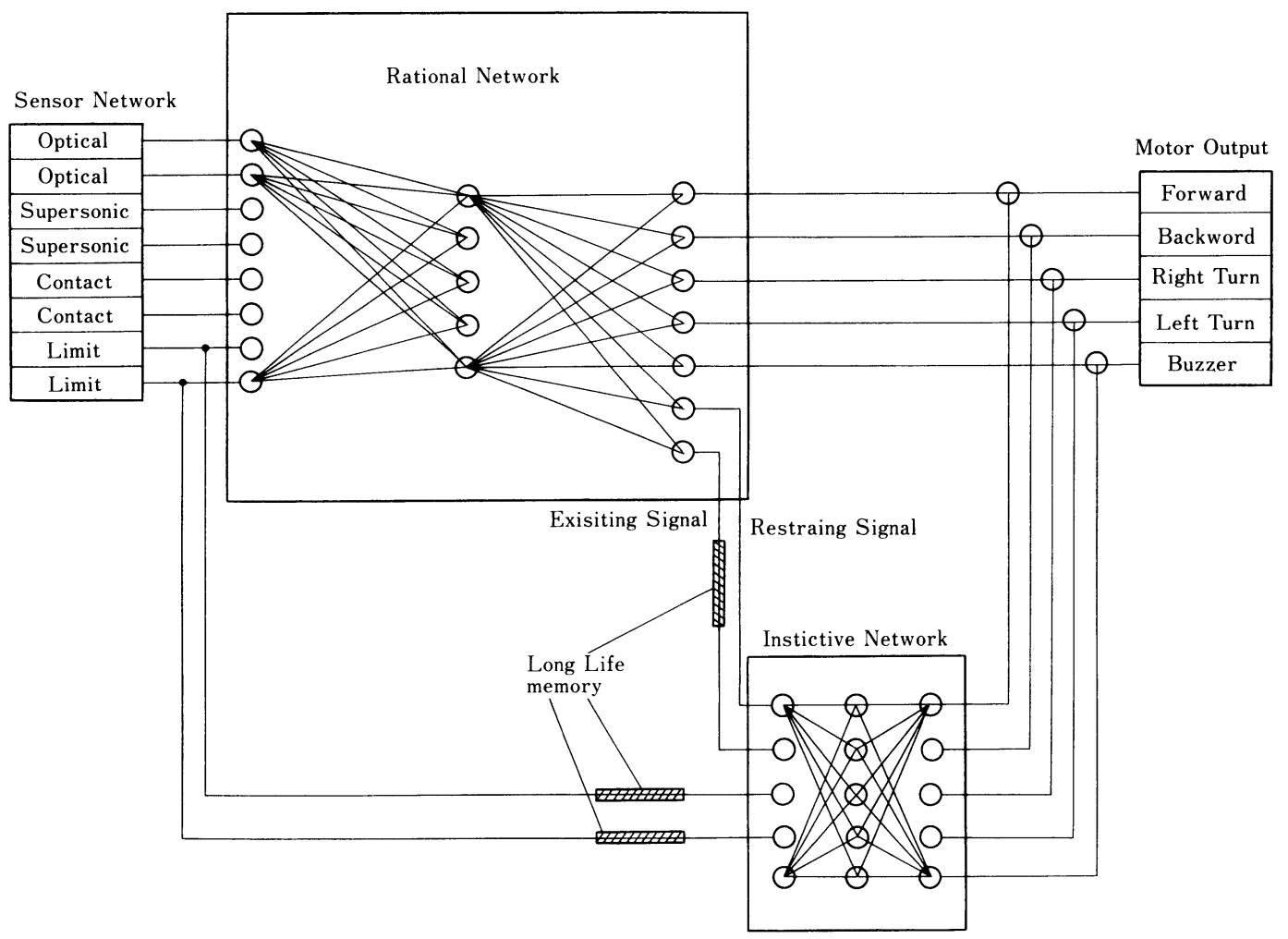

Fig.11 Neural Network 


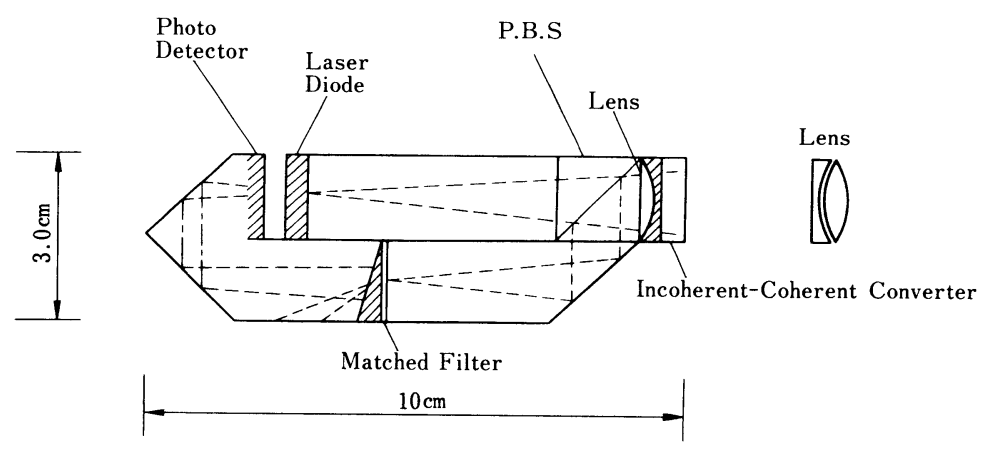

Fig.12 Optical Correlater

憶型ユニットを介して結合されている。

このニューロロボットは, 学習のさせ方, すなわちセ ンサ入力情報と行動パターンの対応関係を変化させる事 で，同一構造のロボットを様々な習性を持ったロボット に変化させる事が可能な柔軟性を持つ。

\section{2 光情報処理ロボットアイ（逐次並列型情報処理）}

最近, 逐次直列情報処理マシンであるノイマン型計算 機（現在の電子計算機）の課題を, 光の本質的特性であ る並列情報処理性で克服しょうとする光情報処理の研究 が盛んである。特に, パターン認識は従来のノイマン型 計算機が最も不得意としているものの1つである。これ を高速に行う技術として，ホログラフィによる光相関演 算技術がある。

Fig.12 ${ }^{12)}$ は, 半導体レーザを用いて小型化した光相関 器の構成図である。結像レンズで取り込んだ入力像と, マッチトフィルタフィルム（標準パターンのフーリエ変 換ホログラム）との光学的フーリ工変換による相関演算 の結果を検出器出力 (光量) から求め, この相関度 (パ ターン類似度）を用いて高速パターン認識を実現してい る。

しかしながら，このような光相関器の標準パターンの フーリ工変換ホログラムの作成は, 基本的に写真プロセ スに立脚している。従って，これをロボット・アイに適 用する場合, 作業内容が変更される都度その対象物体の フーリエ変換ホログラムを撮影し, Fig.12のマッチトフ イルタフィルム面に再配置する必要がある。一方, 従来 の電子計算機ではプログラムの変更で対応できる。

すなわち, 光情報処理は従来の/イマン型計算機と比 較して高速化が図れるが, 作業内容の変更等に対する柔 軟性に欠けるという久点を持っている。そこで, 光情報 処理に柔軟性を持たせ，これをロボット・アイに応用し ようとする研究が盛んになってきている。

Fig.13 ${ }^{13) .14)}$ は, 実時間計算機ホログラムによる形状認 識システムの構成図である。このシステムでは, 実際に

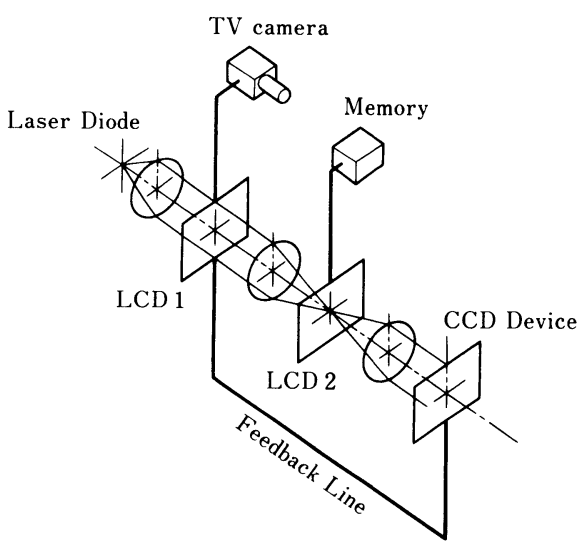

Fig.13 Recoginition System Using Realtime Computor Generated Hologram

標準パターンを置いてそのフーリエ変換ホログラムをフ イルム上に撮影するのではなく, FFT（高速フーリ工変 換）プログラムを用いて計算機ホログラムを作成し，そ れを液晶ディスプレイ上に絵素マトリックスの透過率を 空間的に変調する事で表示するものである。従って, 光 の並列情報処理機能による高速性を推持しつつ, 柔軟性 をも賦与することができる。また，計算機ホログラムに は座標変換等のトポロジカルな機能を与える事が可能な ため単純なパターンマッチング以外の光情報処理を $\mathrm{CCD}$ 素子からの電気的フィードバックにより逐次並列 処理の形で実行可能である。

\section{6.おわりに}

ロボット制御の要素技術としてセンサ技術を中心に, アクチュエー夕技術, AI 技術について三者の位置付けお よび相互の関連という観点で述べてきたが， ロボット制 御技術の今後の動向として, 


\section{1. 高信頼性化}

2. 知能化

の 2 つの大きな流れ，具体的には， 高信頼性化として, 圧電デバイス, Si ベースのマイク ロメカニクス等の研究開発によるセンサ, アクチュエー 夕の固体化, 構造の単純化及び, 複合機能化による素子 数の削減等があげられる。一方, 知能化としてオプトロ ニクス, 光情報処理と知識データベースの導入によるイ ンテリジェントセンサ化， ロボット制御の知的制御技術 化等があげられる。

今後は, このような分野の研究開発がニーズを踏まえ つつ，より盛んになっていくものと考えられる。

\section{参考 - 引用文献}

1）館 他：計測自動制御学会誌， p.1140（S 57-12） 2）若宮：センサ技術，p.93（89-6)

3) 谷口: M\&E, p.112 (88-5)

4）姉崎 他：インテリジェント FA シンポジウム講演 論文集, p.67（JULY，1989）

5）長谷川：センサ技術, p.73 (83-6)

6）日経メカニカル, p.60 (86.7.28)

7）増田 他：計測自動制御学会論文集, p.73（S56-12）

8）谷江 他：精密工学会誌, p.1189 (89-7)

9）樋口 他：'88日本ロボット学会講演論文集, p.75

10）坂根 他：電気学会システム制御研究会, SC-84-18

11）木本 他：電子通信学会研究会, CPSY 88-20

12）三橋：情報処理学会誌, p.909 (85-8)

13）西井 他：89春精密工学会講演論文集, p.957

14）河村 他：89秋精密工学会講演論文集（投稿中） 